УДК 621.784

() М. В. Коробка, аспірант, КПІ ім. Ігоря Сікорського, Київ, Україна

\title{
ПІДВИЩЕННЯ ЕКСПЛУАТАЦІЙНИХ ВЛАСТИВОСТЕЙ ПОЛІГРАФІЧНОГО ОБЛАДНАННЯ
}

\begin{abstract}
Запропоновано двоетапний технологічний процес утворення на плоских направляючих поліграфічного обладнання мікрорельєфних направляючих. Встановлено аналітичну залежність між площею мікронаправляючих і геометричними параметрами мікрорельєфу.

Досліджено вплив режимів обробки на геометричні параметри мікрорельєфу. Експериментально визначено оптимальну, з точки зору зносостійкості, площу мікронаправляючих, виготовлених із металевих деталей.
\end{abstract}

\section{Ключові слова: поліграфічне обладнання; поверхневе пластичне деформування; мікронаправляючі; режими обробки; експлуатаційні властивості.}

\section{Постановка проблеми}

Зважаючи на технічний стан вітчизняного поліграфічного обладнання та необхідність забезпечення показників якості друкованої продукції актуальною $€$ проблема як застосування сучасних технологій переоснащення поліграфічних виробництв, так і оптимізації функціонуючих за рахунок використання технологій підвищення зносостійкості деталей вузлів і механізмів, а також впровадження технологій відновлення.

Деталі вузлів та механізмів поліграфічного обладнання мають безліч геометричних поверхонь пласкі, циліндричні, конусні, фасонні тощо. Вони експлуатуються в різних умовах навантажень: корозія, знос, розтягування, тиск у зоні контакту тощо.
Так, наприклад, для покращення контакту і підвищення зносостійкості на пласкі робочі кромки захватів офсетної друкарської машини Heidelberg MOZ рекомендовано утворювати методом поверхневого пластичного деформування регулярний мікрорельєф (РМ).

Покращує експлуатаційні властивості й утворення на поверхні передавальних циліндрів частково регулярного мікрорельєфу (ЧРМР) із перетином канавок [1].

Значну кількість деталей з пласкими і циліндричними поверхнями, які працюють в умовах тертя мають поточні лінії рулонних офсетних машин. Зазначене поліграфічне обладнання використовується для друку журналів, акцидентної продукції, ілюстративних матеріалів із закріпленням фарби на відбитку гарячим повітрям (Heatset) [1-4]. 
Навантаження, якому піддаються деталі флексографічних і рулонних офсетних машин, ліній для виготовлення інтегральних і півжорстких обкладинок та іншого устаткування ставить відповідні вимоги до геометричних і фізико-механічних параметрів поверхонь і приповерхневих шарів деталей та механізмів поліграфічного обладнання.

\section{Аналіз попередніх досліджень}

Утворення на поверхнях деталей регулярних мікрорельєфів значно підвищує як показники якості приповерхневих шарів, як наслідок, покращуються експлуатаційні властивості.

У роботах [5-7] для підвищення зносостійкості циліндричних поверхонь запропоновано комплексний технологічний процес у два етапи: утворення ЧРМР на першому етапі та утворення повністю регулярного мікрорельєфу тетрагонального або гексагонального типу, для згладжування напливів на другому етапі.

У дослідженнях [8-10] запропоновано комплексний технологічний процес утворення регулярного мікрорельєфу вібраційним обкатуванням з подальшим хромуванням. На першому етапі на поверхні деталей утворюють чРМР з нерівностями, які не перетинаються, а на другому етапі металеву поверхню з ЧРМР хромують.

У роботах $[11,12]$ досліджено комбінований оздоблювальнозміцнюючий технологічний процес пласких поверхонь деталей поліграфічного обладнання шляхом випереджаючого пластичного деформування з наступною обробкою алмазно-абразивним інструментом. При цьому, на поверхні створюють ЧРМР чотирикутного типу, а напливи знімаються алмазно-абразивною обробкою.

У дослідженні [13] запропоновано утворювати на циліндричній поверхні друкарського циліндру ПРМР гексагонального типу. Це дозволяє збільшити площу контакту друкарського циліндру і противідмарювальної металевої пластини. Збільшення площі контакту забезпечує стабільно високу якість друкованого відбитка. На другому етапі поверхню друкарського циліндра з ПРМР піддають хромуванню, що значно підвищує його експлуатаційну зносостійкість.

Враховуючи проведені дослідження, актуальною $є$ гіпотеза про наявність взаємозв'язку між зносостійкістю, геометричною формою і розташуванням на поверхні мікрорельєфу та якістю друкованої продукції.

\section{Мета роботи}

Підвищення параметрів якості та експлуатаційних властивостей деталей направляючих поліграфічного обладнання з пласкими поверхнями за рахунок двоетапної технології утворення на них мікронаправляючих методом поверхневого пластичного деформування.

\section{Результати проведених досліджень}

Для підвищення зносостійкості направляючих запропонована двоетапна технологія утворення мікронаправляючих: на першому етапі на поверхні утворюють мікрорельєф у вигляді кіл. На другому 
етапі зменшують зусилля вдавлювання і утворюють мікропрямолінійну направляючу, що проходить через мікрорельєфні кола.

Для досліджень як зразки направляючих взято пласкі деталі iз Cm40X, HRC 60...63; Cm20X, HRC 49...52; C4-25, HB 190...210.

Площа мікронаправляючої складається з площі кругового сегмента мікрорельєфу і прямолінійної мікрорельєфної направляючої

$$
\begin{aligned}
& S=S_{\text {сег }}+S_{\text {пр }}= \\
& =m\left[\begin{array}{c}
n\left(R^{2} \arccos \left(\frac{d}{R}\right)-\right. \\
\left.-d \sqrt{R^{2}+d^{2}}\right)+2 l d
\end{array}\right],
\end{aligned}
$$

де $\mathrm{S}_{\text {сег }}$ - площа кругового сегмента мікрорельєфу; $S_{п р}$ - площа прямолінійної мікрорельєфної направляючої; $d-0,5$ ширини прямолінійної мікрорельєфної направляючої; R - радіус кола кругового мікрорельєфу; m кількість прямолінійних мікронаправляючих; n - кількість кругових сегментів мікрорельєфу на одній прямолінійній мікронаправляючій.

В табл. представлено вплив режимів обробки поверхневим пластичним деформуванням для різних матеріалів на геометричні параметри мікронаправляючих.

Зразки, для проведення експериментальних досліджень на зносостійкість, мали розміри $50 \times 35 \times 14$ мм.

Площа тертя - 1750 мм² $^{2}$, вага зразка - менше 200 г, середня швидкість руху зразка по зразку 5 м/с. Тиск на зразок, який досліджувався $-150 \mathrm{H} / \mathrm{cm}^{2}$. Знос зразків визначався за допомогою лабораторних аналітичних вагів, їх похибка становила $\pm 0,15$ мг. Лінійний знос визначався по заміру зміни глибини канавки мікрорельєфу.

Вплив режимів обробки поверхневим пластичним деформуванням для різних матеріалів на геометричні параметри

\begin{tabular}{|c|c|c|c|c|c|}
\hline \multirow{2}{*}{$\begin{array}{c}\text { Матеріал } \\
\text { направляючого }\end{array}$} & \multirow{2}{*}{$\begin{array}{l}\text { Зусилля } \\
\text { дефор- } \\
\text { мування }\end{array}$} & \multirow{2}{*}{$\begin{array}{c}\text { Радіус } \\
\text { сфери } \\
\text { інстру- } \\
\text { мента }\end{array}$} & \multicolumn{3}{|c|}{$\begin{array}{c}\text { Геометричні параметри } \\
\text { мікрорельєфу }\end{array}$} \\
\hline & & & ширина & глибина & $\begin{array}{c}\text { висота } \\
\text { напливів }\end{array}$ \\
\hline $\begin{array}{l}\text { Cm40x, } \\
\text { HRC 61...64 }\end{array}$ & & & & & \\
\hline 1 етап & 300 & 1,5 & 0,3 & 0,0036 & 0,0013 \\
\hline 2 етап & 200 & 1,5 & 0,25 & 0,0024 & 0,0008 \\
\hline $\begin{array}{l}\text { Cm20x, } \\
\text { HRC 49...52 }\end{array}$ & & & & & \\
\hline 1 етап & 250 & 2,0 & 0,31 & 0,0038 & 0,0013 \\
\hline 2 етап & 200 & 2,0 & 0,26 & 0,0028 & 0,0008 \\
\hline $\begin{array}{l}\text { C } 425 \\
\text { HB 190...210 }\end{array}$ & & & & & \\
\hline 1 етап & 180 & 4,0 & 0,46 & 0,0060 & 0,0026 \\
\hline 2 етап & 120 & 4,0 & 0,38 & 0,0032 & 0,0020 \\
\hline
\end{tabular}
мікронаправляючих 
Для цього використовувався профілометр модель 296 і комп'ютер IBM PC з мікропроцесором. Діапазон вимірювань 0,02-10 мкм. Похибка вимірювань не перевищувала $10 \%$, довжина шляху вимірювань щупом 1,5 мм; 3 мм, 6 мм.

За цикл вимірювань було прийнято 300000 ходів зразка, що притискується до досліджуваного зразка. Це відповідає 10000 м шляху тертя.

Пласкі зразки на знос досліджувались на спеціальному стенді (рис.).

Нижній металевій зразок 1 закріплено в затискному механізмі 2, який кріпиться до столу фрезерного верстата. Рухомий зразок 4 кріпиться в тримачі 5. Зворотно-поступальні осциляції передаються рухомому зразку 4 від шпинделя верстата за рахунок механізму 6. Навантаження на нерухомий зразок 1 від рухомого зразка 4 передавалось вертикальним переміщенням стола верстата за рахунок стискання тарированої пружини, закріпленої в тримачі 5. За необхідності в зону тертя може подаватись крапельницею 7 мастильне масло. Перед проведенням досліджень проводилось тарерування динамометра пристрою.

Зразки попередньо очищались, промивались в ацетоні, спирті, сушились, зважувались і записувались на профілографі глибини мікрорельєфу. Потім зразок, що досліджувався кріпився в затискному механізмі і підтискувався рухомим зразком із заданим зусиллям.

Наступнім кроком було включення привода пристрою. Після семи годин тертя зразок знімався, очищався, промивався в ацетоні, спирті, сушився, зважувався і за вагою визначався знос. На профілометрі записувалась глибина канавки мікрорельєфу і визначався лінійний знос.

На зразках утворювали мікрорельєф площею 20 \%, 25 \%, 30 \% та 35 \%. Результати проведених експериментальних досліджень показали, що найкращі результати зносостійкості були досягнуті на зразках з площею 25 \% та 30 \%.

Після проведення повторних уточнюючих експериментів з площею на зразках мікрорельєфів

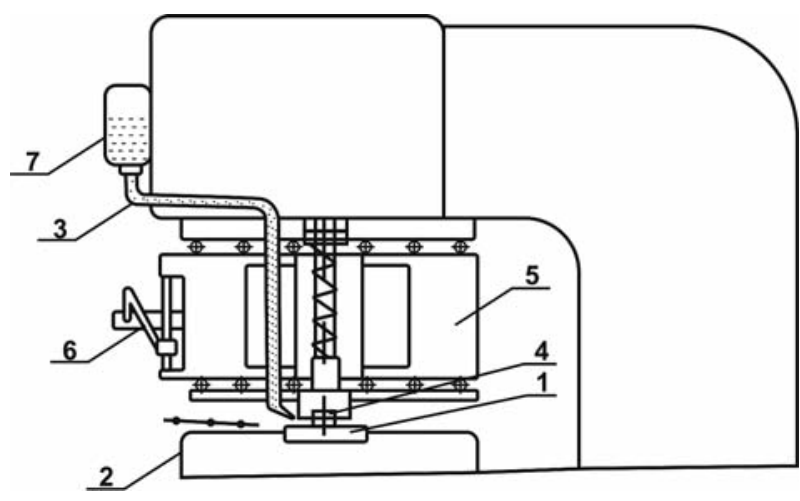

Схема стенда для проведення випробувань 
25-30 \% отримані наступні результати: для направляючих, виготовлених зі сталі оптимальною $€$ площа мікрорельєфу - $26 \%$... $30 \%$, а для чавуна - $25 \%$...28 \%. Результати проведених досліджень показали, що зносостійкість пласких поверхонь з мікрорельєфом на поверхні в $1,2 \ldots 1,4$ рази більше пласких шліфованих поверхонь.

Утворення мікрорельєфу поверхневим пластичним деформуванням супроводжується значним зміцненням приповерхневого шару. Мікротвердість збільшується на $24 \ldots 26 \%$.

\section{Висновки}

Запропоновано двоетапний технологічний процес утворення мікронаправляючих, що дозволяє підвищити зносостійкість направляючих в 1,3...1,4 рази порівняно з пласкими шліфованими поверхнями.

Двоетапна технологія підвищує мікротвердість приповерхневого шару мікронаправляючих, що також сприяє підвищенню експлуатаційних властивостей направляючих. Досліджено вплив режимів обробки на геометричні параметри мікронаправляючих.

Встановлено аналітична залежність площі мікронаправляючих від геометричних параметрів мікрорельєфу.

Експериментально визначено оптимальну площу мікронаправляючих для металів, що досліджувались.

\section{Список використаної літератури}

1. Несхозієвська Т. М. Зміцнення поверхонь деталей аркушепровідних систем офсетних друкарських машин / Т. М. Несхозієвська, П. О. Киричок, О. І. Лотоцька // Наукові вісті УАД. 2013. № 4. С. 93-98.

2. Спосіб покращення експлуатаційних властивостей захватів аркушепередавальної системи аркушевих офсетних друкарських машин. Пат. № 79894, МПК(2013.01) В41F 31/00 B41N 7/00. Несхозієвський А. В., Несхозієвська Т. М., Киричок П. О. NU201210682, заявлено 12.09.2012р.; опубліковано 13.05.2013 р. Бюл. № 9.

3. Спосіб прискорення відновлення друкарських циліндрів аркушевих друкарських машин. Пат. № 82233, МПК(2013.01) B41F 31/00, B41F 21/00, B41N 7/00. Несхозієвський А. В., Киричок А. П., Несхозієвська Т. М. № U201301786, заявлено 13.02.2013 р.; опубліковано 25.07.2013 р. Бюл. № 14.

4. Спосіб покращення експлуатаційних властивостей та зносостійкості зволожувальних валів офсетних друкарських машин. Пат. № 79895, МПК(2013.01)B41F31/00, В41N 7/00. Несхозієвський А. В., Несхозієвська Т. М., Киричок П. О., Нестеренко В. М. № U201210683, заявлено 12.09.2012 р.; опубліковано 13.05.2013 р. Бюл. № 9.

5. Киричок П. О. Комплексна оздоблювально-зміцнююча обробка / П. О. Киричок, О. І. Хмілярчук // Технологія і техніка друкарства. 2005. № 2. С. 73-78.

6. Спосіб утворення мікрорельєфу. Пат. 10734А, МПК В24В39/00/. П. О. Киричок, О. І. Хмілярчук. № 200500258, заявлено 10.06.05 р.; опубліковано 15.11.05. Бюл. № 11.

7. Киричок П. О. Комбіновані способи поверхневого пластичного деформування деталей поліграфічного обладнання / П. О. Киричок, О. І. Хмілярчук // Технологія і техніка друкарства. 2006. № 3. С. 74-81. 
8. Лотоцька О. І. Підвищення експлуатаційних властивостей деталей поліграфічних машин / О. І. Лотоцька // Технологія і техніка друкарства. 2008. № 3-4(21-22). C. 16-20. DOI: https://doi.org/10.20535/2077-7264.34(21-22).2008.58790.

9. Лотоцька О. І. Сучасні фінішні методи підвищення експлуатаційних властивостей деталей поліграфічних машин поверхностним пластичним деформуванням і хромуванням / О. І. Лотоцька // Технологія і техніка друкарства. 2010. № 2(28). C. 44-50. DOI: https://doi.org/10.20535/2077-7264.2(28). 2010.56079.

10. Спосіб утворення регулярного мікрорельєфу. Пат. № 55748 , МПК В24В 39/00. Киричок П. О., Лотоцька О. І. № U201006779, заяв. 01.06.2010 р.; опубліковано 27.12.2010 р. Бюл. № 24.

11. Олійник В. Г. Теоретичне і експериментальне дослідження опоряджувально-зміцнюючої обробки деталей поліграфічного обладнання / В. Г. Олійник // Технологія і техніка друкарства. 2006. № 2. С. 149-153.

12. Спосіб комбінованої обробки поверхонь деталей. Пат. № 18482 , МПК В24В 39/00. Киричок П. О., Хмілярчук О. І., Олійник В. І. Опубліковано 15.11.2006 р. Бюл. № 11.

13. Спосіб утворення повністю регулярного мікрорельєфу на друкарських циліндрах. Пат. № 81661, МПК В41N 10/00, B41N 7/00. Киричок П. О., Зігуля С. М. № 201214875, заявлено 25.12.2012р.; опубліковано 10.07.2013 р. Бюл. № 13.

\section{References}

1. Neskhoziievska, T. M. \& Kyrychok, P. O. \& Lototska, O. I. (2013). Zmitsnennia poverkhon detalei arkusheprovidnykh system ofsetnykh drukarskykh mashyn. Journal of Naukovi visti UAD, 4, 93-98 [in Ukrainian].

2. Neskhoziievskyi, A. V. \& Neskhoziievska, T. M. \& Kyrychok, P. O. Sposib pokrashchennia ekspluatatsiinykh vlastyvostei zakhvativ arkusheperedavalnoi systemy arkushevykh ofsetnykh drukarskykh mashyn [The method of improving the performance of the grips of the sheet-fed system of sheet-fed offset printing machines] // Patent № 79894. Publish 13.05.2013 [in Ukrainian].

3. Neskhoziievskyi, A. V. \& Kyrychok, A. P. \& Neskhoziievska, T. M. Sposib pryskorennia vidnovlennia drukarskykh tsylindriv arkushevykh drukarskykh mashyn [Method of accelerating recovery of printing cylinders of sheet-fed printing machines] // Patent № 82233. Publish 25.07.2013 [in Ukrainian].

4. Neskhoziievskyi, A. V. \& Neskhoziievska, T. M. \& Kyrychok, P. O. \& Nesterenko, V. M. Sposib pokrashchennia ekspluatatsiinykh vlastyvostei ta znosostiikosti zvolozhuvalnykh valiv ofsetnykh drukarskykh mashyn [Method of improving performance properties and wear resistance of humidifying shafts of offset printing machines] // Patent № 79895. Publish 13.05.2013 [in Ukrainian].

5. Kyrychok, P. O. \& Khmiliarchuk, O. I. (2005). Kompleksna ozdobliuvalnozmitsniuiucha obrobka. Journal of Tekhnolohiia i tekhnika drukarstva, 2, 73-78 [in Ukrainian].

6. Kyrychok, P. O. \& Khmiliarchuk, O. I. Sposib utvorennia mikroreliefu [The method of microrelief formation] // Patent 10734A. Publish 15.11.05 [in Ukrainian].

7. Kyrychok, P. O. \& Khmiliarchuk, O. I. (2006). Kombinovani sposoby poverkhnevoho plastychnoho deformuvannia detalei polihrafichnoho obladnannia. Journal of Tekhnolohiia i tekhnika drukarstva, 3, 74-81 [in Ukrainian]. 
8. Lototska, O. I. (2008). Pidvyshchennia ekspluatatsiinykh vlastyvostei detalei polihrafichnykh mashyn. Journal of Tekhnolohiia i tekhnika drukarstva, 3-4(21-22), 16-20. DOI: https://doi.org/10.20535/2077-7264.3-4(2122).2008.58790 [in Ukrainian].

9. Lototska, O. I. (2010). Suchasni finishni metody pidvyshchennia ekspluatatsiinykh vlastyvostei detalei polihrafichnykh mashyn poverkhnostnym plastychnym deformuvanniam i khromuvanniam. Journal of Tekhnolohiia i tekhnika drukarstva, 2(28), 44-50. DOI: https://doi.org/10.20535/2077-7264.2(28). 2010.56079 [in Ukrainian].

10. Kyrychok, P. O. \& Lototska, O. I. Sposib utvorennia rehuliarnoho mikroreliefu [The method of formation of a regular microrelief] // Patent № 55748. Publish 27.12.2010 [in Ukrainian].

11. Oliinyk, V. H. (2006). Teoretychne i eksperymentalne doslidzhennia oporiadzhuvalno-zmitsniuiuchoi obrobky detalei polihrafichnoho obladnannia. Journal of Tekhnolohiia i tekhnika drukarstva, 2, 149-153 [in Ukrainian].

12. Kyrychok, P. O. \& Khmiliarchuk, O. I. \& Oliinyk, V. I. Sposib kombinovanoi obrobky poverkhon detalei [The method of combined surface treatment of parts] // Patent № 18482. Publish 15.11.2006 [in Ukrainian].

13. Kyrychok, P. O. \& Zihulia, S. M. Sposib utvorennia povnistiu rehuliarnoho mikroreliefu na drukarskykh tsylindrakh [Method of forming completely regular microrelief on printing cylinders] // Patent № 81661. Publish 10.07.2013 [in Ukrainian].

Проведен литературный анализ и патентный поиск технологических процессов создания полностью и частично регулярных микрорельефов разных видов при помощи поверхностного пластического деформирования, определена необходимость создания на плоских поверхностях комбинированного микрорельефа с задачей улучшения параметров качества и эксплуатационных характеристик направляющих.

Разработанная двухэтапная технология позволяет увеличить износостойкость направляючих в 1,3-1,4 раза по сравнению с плоским шлифованными поверхностями, а также улучшение геометрических и физико-механических параметров поверхности деталей полиграфического оборудования.

Ключевые слова: полиграфическое оборудование; поверхностное пластическое деформирование; микронаправляющие; режим обработки; эксплуатационные свойства.

A two-stage technological process of formation of microrelief on flat guides of polygraphic equipment is proposed. 
An analytical dependence between the area of micro-directional and geometrical parameters of micro-relief is established.

The influence of processing modes on the geometric parameters of micro-relief is investigated. The optimum, from the point of view of wear resistance, the area of microproducts made of metal parts has been experimentally determined.

Keywords: printing equipment; surface plastic deformation; micro-guides; processing mode; operational properties.

Рецензент - О. О. Палюх, канд. техн. наук, доц., КПІ ім. Ігоря Сікорського 